\title{
PERCEPTION OF ECONOMICS UNDERGRADUATE ON NON- USAGE OF UNIVERSITY'S ICT PLATFORM IN TEACHING ECONOMICS IN UNIVERSITY OF ILORIN
}

Bello Muhinat Bolanle, Yusuf AbdulRaheem, Amali Oteikwu Ismail ${ }^{1}$

\begin{abstract}
This study investigated the perception of economics undergraduate on non-usage of the university's ICT platform in teaching economics at the University of Ilorin. Descriptive research of survey type was adopted in this study. The population of this study consists of all Economics undergraduate in the departments of Economic and Economics Education (of the social sciences education department) which is estimated at 937 students. A sample of 278 respondents was drawn randomly in this study. A Researcher's Designed questionnaire with psychometric properties of content validity and $0.71 \mathrm{r}$ was used to elicit the needed. Data collected were analyzed with descriptive statistics of frequency counts, percentages, means, and standard deviation while the hypotheses formulated were tested using inferential statistics of t-test and ANOVA at 0.05 alpha levels. The study revealed that lecturer's philosophy, lack of appropriate skills, incompatible classroom environment, limited lecture hours and non-satisfaction with ICT results, among others are perceived as reasons for non-usage of ICT platforms for teaching economics. The study, therefore, recommended that the use of visual Google classroom at all levels of the teaching by the university administration should be encouraged.
\end{abstract}

Keywords: Perception, Reasons, ICT Platforms and Non-Usage. 


\section{Introduction}

The emergence of technologies for learning, conversation media and smart interface, Open Educational Resources (or Massively Open Online Courses) and increased awareness of "New Generation" have been demanding traditional education and learning systems to be more open, flexible, and customized to what students want to expect. Using ICT in education has been widely accepted as an effective way of challenging such changes attributed to technological advances, societal paradigm shift, and internationalization. It is based on the strong belief that the potential of ICT would bring positive impacts to teaching and learning by providing students and teachers with flexibility, accessibility, more opportunities for participation and collaboration, and more outcomes.

Now is the right time to respond to a simple but critically important question, "what should be done to fully exploit valuable resources for better education in the future?" It would be to use all resources in a smart way to maximize their potentials to meet the different perspectives on ICT from stakeholders: teachers, students, and academic institutions. It is in response to this that the University of Ilorin under the leadership of Professor Abdulganiyu Ambali, decided to make available to all students of the instruction for four years a tablet. This is considered to be very portable, internet access and also subscribe to the Google Apps platform where both lecturers and students are accommodated to effectively carry out their teaching and learning the process. But one question anybody will ask today is how well are lecturers exploring this platform to teach their students?

This is because changes in technology, demography, and internationalization are driving education system to evolve to an open flexible education (or learning) environment which provides learners with quality services encompassing formal, informal, and non-formal education. 
To this regard the "Learning for the Future (LFF)" project recently initiated by UNESCO IITE is a comprehensive approach to integrate ICT in education, renew pedagogy, and enhance learning now and the future, which ensures teachers and students effective use of technologies and resources in strengthening the four pillars of learning for the $21^{\text {st }}$ century: learning to know, learning to do, learning to be, and learning to live together.

ICTs have the potential to accelerate, enrich, and deepen skills, to motivate and engage students, to help relate school experience to work practices, create economic viability for tomorrow's workers, as well as strengthening teaching and helping schools change (Davis and Tearle, 1999; Lemke and Coughlin, 1998; cited by Yusuf, 2005). In a rapidly changing world, basic education is essential for an individual to be able to access and apply information. Such ability must find include ICTs in the global village.

Conventional teaching has emphasized content. For many years the course has been written around textbooks. Teachers have taught through lectures and presentations interspersed with tutorials and learning activities designed to consolidate and rehearse the content. Contemporary settings are now favoring curricula that promote competency and performance. Curricula are starting to emphasize capabilities and to be concerned more with how the information will be used than with what the information is. Contemporary ICTs are able to provide strong support for all these requirements and there are now many outstanding examples of world class settings for competency and performance-based curricula that make sound use of the affordances of these technologies (Oliver, 2000). The use of information and communication technologies can help revitalize teachers and students. This can help to improve and develop the quality of education by providing curricular support in difficult subject areas. To achieve these objectives, teachers need to be involved in collaborative projects and the development of intervention change strategies, which 
would include teaching partnerships with ICT as a tool. According to Zhao and Cziko (2001), three conditions are necessary for teachers to introduce and use ICT in their classrooms or teaching: teachers should believe in the effectiveness of technology, teachers should believe that the use of technology will not cause any disturbances, and finally teachers should believe that they have control over technology. However, research studies show that most teachers do not make use of the potential of ICT to contribute to the quality of learning environments, although they value this potential quite significantly (Smeets, 2005). Harris (2002) conducted case studies in three primary and three secondary schools, which focused on innovative pedagogical practices involving ICT. Harris (2002) concludes that the benefits of ICT will be gained "... when confident teachers are willing to explore new opportunities for changing their classroom practices by using ICT. As a consequence, the use of ICT will not only enhance learning environments but also prepare the next generation for future lives and careers (Wheeler, 2001). The changed pool of teachers will come changed responsibilities and skill sets for future teaching involving high levels of ICT and the need for more facilitative than didactic teaching roles (Littlejohn et al., 2002).

According to Cabero (2001), «the flexibilization time-space accounted for by the use of ICT in teaching and learning processes contributes to increasing the interaction and reception of information. Such possibilities suggest changes in the communication models and the teaching and learning methods used by teachers, giving way to new scenarios which favor both individual and collaborative learning". The use of ICT in educational settings, by itself, acts as a catalyst for change in this domain. ICTs by their very nature are tools that encourage and support independent learning. Students using ICTs for learning purposes become immersed in the process of learning and as more and more students use computers as information sources and cognitive tools (Reeves \& Jonassen, 1996), the influence of the technology on supporting how students learn will continue to increase. 
In the past, the conventional process of teaching has revolved around teachers planning and leading students through a series of instructional sequences to achieve the desired learning outcome. Typically these forms of teaching have revolved around the planned transmission of a body of knowledge followed by some forms of interaction with the content as a means to consolidate the knowledge acquisition. Contemporary learning theory is based on the notion that learning is an active process of constructing knowledge rather than acquiring knowledge and that instruction is the process by which this knowledge construction is supported rather than a process of knowledge transmission (Duffy \& Cunningham, 1996). In this domain, learning is viewed as the construction of meaning rather than as the memorization of facts (Lebow, 1993; Jonassen \& Reeves, 1996). Learning approaches using contemporary ICTs provide many opportunities for constructivist learning through their provision and support for resourcebased, student-centered settings and by enabling learning to be related to context and to practice (Berge, 1998; Barron, 1998). Students enjoy learning, and the independent inquiry which innovative and appropriate use of ICT can foster. They begin to acquire the important of 21 st-century skills which they will need in their future lives.

Many variables may account for reason lecturers find it difficult to adopt the use of ICT for their lecturers in higher institutions, some which are: government, environmental, lecturers, students and lastly parents various (Zhao \& Cziko, 2001). In the work of Susman (1998) it was revealed that Lecturers' variable factors influence their attitude and use of ICT in teaching negatively. Tedla (2012) and Tay, Lim, Lim and Ling-Koh (2012) confirm that lecturers use ICT tools in order to make the lessons more interesting and engage learners according to learners' potentials. Also in the study conducted by Flecknoe (2002), the finding revealed $67.5 \%$ of respondents' perceptive teachers' level of teaching experience determines the extent to which lecturer uses modern technologies in delivering instructions in the classroom. For instance, it was an acclaimed number 
of years of classroom experience reduce certain teachers' beliefs because experienced lecturers were more likely to believe that classrooms should be lecturers' centered and that learning did not always need to be fun". Teachers' age, their level of computer experience and they are lent of years spent at pre-service was and perceived as having serious influence ICT integration (Teo, 2008).

If students are asked to comment on the state or quality of teaching they received without the use of ITC platform provided by the school to them despite their assess to Tablet Portable Computer and Wi-Fi, they are likely to differ in their reasons for avoidance of ICT by their lecturers. This is because the International Encyclopedia of Social Sciences, (1992) defines perception as the process by which one comes to know and think about others and their work, characteristics, qualities, roles and functions in the society. It adds that when several individuals confront an object or a thing in their environment, the input of information that impinges on their respective sense organs (e.g. eyes and ears) is the same for every individual, though they may perceive it differently. In Hornby's (1991) view, perception is believed to be the ability to show understanding and insight, to be able to notice and have discernment about a situation. Similarly, Miller and McCracken (1988) posit that perception is the ability of a person to know about his environment through the use of his sense organs which must be very active. Various explanations can be offered as to why the individuals perceive the same thing differently, even when they are confronted with the same stimulus. The Encyclopedia Britannica (1997) identifies some variables as responsible for differences in the perceptual functioning of an individual, age, status, gender, among others.

The gender of an individual is considered an important factor that influence perception in not-usage of University ICT platform in the teaching of economics in the University of Ilorin, due to the differences which male and female members of these areas experienced. The positions an individual occupies in the society also influence their perception of 
issues and situation (status).

Perception is the mental function of giving significance to stimuli such as shapes, color, movement, taste, sounds, touch, smells, pains, pressures and feeling. Perceptions give rise to individual behavioral responses to particular situations.

\section{Statement of the Problems}

The study has shown that an estimated percentage of University lecturers do not explore the ICT platforms available for them, in order to make teaching and learning more meaningful. This cut across all the faculties and departments, with exception of few departments. This became a source of concern to the school administration which calls for a meeting held with the academic staff of the university trying to create awareness of facilities available to on the university ICTs platform for effective teaching and learning process. Thus, series of workshops, training and re-training of the academic staff of the university by the Centre for Research Development and In-House (Credit) on the use of some of the facilities made available for lecturers on the internet such as Google App classroom. Also, the Institute of Education organized a Training workshop titled "Migration of M.Ed. Sandwich programme to E-learning Platform." All these aimed at exposing lecturers to the integrate ICTs platform available for them to use in class. But up till now students portable tablets have not been put into proper use since lecturers are not taking them up on how best to use it for learning possess. Report of economics undergraduate affirm that out of many courses undergraduate undertakes in the department only two has ever explored ICT to teach STATA software and sharing of software textbooks for two microeconomics courses briefly. A cursory look at the table of the performance of economics undergraduate revealed thus: 
Table 2: Performance of Economics Undergraduates over three Academic Sessions

\begin{tabular}{|l|l|l|}
\hline Academic Session & \% Passed & \% Failed \\
\hline $2013 / 2014$ & 84.95 & 15.05 \\
\hline $2014 / 2015$ & 88.27 & 11.73 \\
\hline $2015 / 2016$ & 92.86 & 7.14 \\
\hline
\end{tabular}

Source: Data Base of University of Ilorin 2017

The above table shows a positive trend of the performance of students over the three academic sessions of the introduction of Portable Tablet Pc for students. This shows that despite non-usage of University ICTs platform economics undergraduates have been performing very well. But in order to compete favorably with global best practices, there is a need for a paradigm shift. Not only to better performance but also to make learning more flexible. In lieu of this, the paper seeks the perception of Undergraduate Economics students on non-usage of University ICT platforms for teaching Economics courses.

\section{Purpose of the Study}

The main purpose of this study was to investigate the perception of undergraduate Economics of non-usage of the university's ICT platform in teaching economics at the University of Ilorin. Specifically the study:

1. Examine the perception of undergraduate economics on non-usage of the university's ICT platform in teaching economics at the University of Ilorin.

2. Ascertain whether there is a difference in the perception of undergraduate economics on non-usage of university's ICT platform in teaching economics at the University of Ilorin on the basis of gender.

3. Ascertain whether there is a difference in the perception of 
undergraduate economics on non-usage of university's ICT platform in teaching economics at the University of Ilorin on $t h \quad \mathrm{~h}$ basis of the level of their education.

\section{Research Questions}

The following questions were raised to guide the study.

1. What is the perception of undergraduate economics on non-usage of the university's ICT platform in teaching economics at the University of Ilorin?

2. Is there a difference in the perception of undergraduate economics on non-usage of the university's ICT platform in teaching economics at the University of Ilorin on the basis of gender?

3. Is there a difference in the perception of undergraduate economics on non-usage of the university's ICT platform in teaching economics at the University of Ilorin on the basis of level?

\section{Research Hypotheses}

The following formulated hypotheses were tested in this study.

$\mathrm{Ho}_{1}$ There is no significant difference in the perception of male and female undergraduate economics on non-usage of university's ICT platform in teaching economics at the University of Ilorin.

$\mathrm{Ho}_{2}$ There is no significant difference in the perception of undergraduate economics on non-usage of university's ICT platform in teaching economics in University of Ilorin on the basis of the level of their education.

\section{Methodology}

Descriptive research of a survey method was employed in the study. The choice of the descriptive survey was in line with Akuezuilo and Agu (2003), who maintained that it is concerned with a gathering of information on peoples' opinion. The population for the study consists of all Undergraduates' of Business and Social Sciences faculty while the target population was the Economics Department, Faculty of Business and Social Sciences, University of Ilorin. Purposive sampling technique was 
used to select the Economics Department which comprises of 937 students. Proportionate sampling technique was used to draw 278 respondents based on the required sample size as stipulated in The Research Advisors (2006) table for sample selection. See table below:

Table 2: Sample Size Selection of Economic and Economics Education Students

\begin{tabular}{|l|l|l|}
\hline Level & Population & Sample Selected \\
\hline 100 & 283 & 84 \\
\hline 200 & 194 & 58 \\
\hline 300 & 203 & 60 \\
\hline 400 & 257 & 76 \\
Total & $\mathbf{9 3 7}$ & $\mathbf{2 7 8}$ \\
\hline
\end{tabular}

Source: (Faculty of Education and Faculty of Social Sciences' IT Office, 2017)

The instrument used for the collection of data was a researcherdesigned questionnaire, which was tagged "Perception of Undergraduate on Non-usage of ICT Platform in Teaching Economics Questionnaire (PUNIPTEQ) with psychometric properties of contents validity and reliability index of 0.71 . The questionnaire was divided into two sections ' $A$ ' and 'B'. Section 'A' contains demographic information of the respondents like Gender and Educational Level while section B consists of items that elicit information on perception of economics undergraduates on nonusage of ICT in Teaching Economics. The questionnaire was structured on four points Likert-type scale as thus: SA- Strongly Agree; A- Agree; D- Disagree; SD- Strongly Disagree. The coding of the questionnaire was $\mathrm{SA}=4 ; \mathrm{A}=3 ; \mathrm{D}=2 ;$ and $\mathrm{SD}=1$. The data collected were analyzed with the use of descriptive statistics of frequency count, percentage, mean and frequency count answer the only research question, while the two hypotheses formulated, was tested using t-test ( $\mathrm{t}$ ) and ANOVA (F) inferential statistics at 0.05 level of significance. 


\section{Results}

Research Question One: What is the perception of economics undergraduate on non-usage of university's ICT platform in teaching economics in University of Ilorin?

Table 3: Responses on the perception of non-usage of ICT platform in teaching economics

\begin{tabular}{|c|c|c|c|c|c|c|}
\hline Items & $\begin{array}{l}\text { SA } \\
(\%)\end{array}$ & $\begin{array}{l}\text { A } \\
(\%)\end{array}$ & $\begin{array}{l}\text { D } \\
(\%)\end{array}$ & $\begin{array}{l}\text { SD } \\
(\%)\end{array}$ & Std. & Mean \\
\hline $\begin{array}{l}\text { The irregular power supply is } \\
\text { considered as one of the reasons } \\
\text { why some economics lecturers } \\
\text { do not use ICT platform for } \\
\text { teaching. }\end{array}$ & $\begin{array}{l}71 \\
(25.5 \%)\end{array}$ & $\begin{array}{l}112 \\
(40.3 \%)\end{array}$ & $\begin{array}{l}52 \\
(18.7 \%)\end{array}$ & $\begin{array}{l}43 \\
(15.5 \%)\end{array}$ & 1.00 & 2.76 \\
\hline $\begin{array}{l}\text { Lack of awareness of economic } \\
\text { lecturers about available ICT } \\
\text { platforms in the university } \\
\text { contributes to non-usage of ICT } \\
\text { platform for teaching. }\end{array}$ & $\begin{array}{l}24 \\
(8.6 \%)\end{array}$ & $\begin{array}{l}79 \\
(28.4 \%)\end{array}$ & $\begin{array}{l}129 \\
(46.4 \%)\end{array}$ & $\begin{array}{l}46 \\
(16.5 \%)\end{array}$ & 0.84 & 2.29 \\
\hline $\begin{array}{l}\text { The process of setting up ICT } \\
\text { platform for lectures is time- } \\
\text { consuming to some senior } \\
\text { lecturers. }\end{array}$ & $\begin{array}{l}49 \\
(17.6 \%)\end{array}$ & $\begin{array}{l}147 \\
(52.9 \%)\end{array}$ & $\begin{array}{l}70 \\
(25.2 \%)\end{array}$ & $\begin{array}{l}12 \\
(4.3 \%)\end{array}$ & 0.76 & 2.84 \\
\hline $\begin{array}{l}\text { Fluctuation in the university's } \\
\text { WiFi's connection jeopardizes } \\
\text { lecturers' interest in using ICT } \\
\text { platform for teaching. }\end{array}$ & $\begin{array}{l}81 \\
(29.1 \%)\end{array}$ & $\begin{array}{l}127 \\
(45.7 \%)\end{array}$ & $\begin{array}{l}51 \\
(18.3 \%)\end{array}$ & $\begin{array}{l}19 \\
(6.8 \%)\end{array}$ & 0.87 & 2.97 \\
\hline $\begin{array}{l}\text { Incompatible classroom } \\
\text { environments to cater for needs } \\
\text { of instructors contribute to } \\
\text { non-usage of ICT platform for } \\
\text { teaching. }\end{array}$ & $\begin{array}{l}72 \\
(25.9 \%)\end{array}$ & $\begin{array}{l}147 \\
(52.9 \%)\end{array}$ & $\begin{array}{l}44 \\
(15.8 \%)\end{array}$ & $\begin{array}{l}15 \\
(5.4 \%)\end{array}$ & 0.80 & 2.99 \\
\hline $\begin{array}{l}\text { Insufficient equipment also } \\
\text { hampers usage of ICT platform } \\
\text { for teaching among economics } \\
\text { lecturers. }\end{array}$ & $\begin{array}{l}90 \\
(32.4 \%)\end{array}$ & $\begin{array}{l}136 \\
(48.9 \%)\end{array}$ & $\begin{array}{l}40 \\
(14.4 \%)\end{array}$ & $\begin{array}{l}12 \\
(4.3 \%)\end{array}$ & 0.80 & 3.09 \\
\hline $\begin{array}{l}\text { Lack of appropriate skills and } \\
\text { knowledge in using computers } \\
\text { hindered integration of ICT } \\
\text { platforms for teachings among } \\
\text { lecturers. }\end{array}$ & $\begin{array}{l}71 \\
(25.5 \%)\end{array}$ & $\begin{array}{l}131 \\
(47.1 \%)\end{array}$ & $\begin{array}{l}58 \\
(20.9 \%)\end{array}$ & $\begin{array}{l}18 \\
(6.5 \%)\end{array}$ & 0.85 & 2.92 \\
\hline $\begin{array}{l}\text { Lecturers' philosophy regarding } \\
\text { appropriate teaching methods } \\
\text { determined whether and how } \\
\text { they used ICT platforms for } \\
\text { teaching. }\end{array}$ & $\begin{array}{l}85 \\
(30.6 \%)\end{array}$ & $\begin{array}{l}136 \\
(48.9 \%)\end{array}$ & $\begin{array}{l}47 \\
(16.9 \%)\end{array}$ & $\begin{array}{l}10 \\
(3.6 \%)\end{array}$ & 0.79 & 3.07 \\
\hline $\begin{array}{l}\text { Inadequate staff development } \\
\text { opportunities hinder some } \\
\text { lecturers from using ICT } \\
\text { platforms for teaching and } \\
\text { learning purpose. }\end{array}$ & $\begin{array}{l}54 \\
(19.4 \%)\end{array}$ & $\begin{array}{l}139 \\
(50.0 \%)\end{array}$ & $\begin{array}{l}74 \\
(26.6 \%)\end{array}$ & $\begin{array}{l}11 \\
(4.0 \%)\end{array}$ & 0.77 & 2.85 \\
\hline
\end{tabular}




\begin{tabular}{|c|c|c|c|c|c|c|}
\hline $\begin{array}{l}\text { Some economics lecturers are } \\
\text { not satisfied with the result } \\
\text { of the usage ICT platform in } \\
\text { teaching economics. }\end{array}$ & $\begin{array}{l}50 \\
(18.0 \%)\end{array}$ & $\begin{array}{l}120 \\
(43.2 \%)\end{array}$ & $\begin{array}{l}87 \\
(31.2 \%)\end{array}$ & $\begin{array}{l}21 \\
(7.6 \%)\end{array}$ & 1.39 & 2.78 \\
\hline $\begin{array}{l}\text { Students attitude towards } \\
\text { plagiarizing answers through } \\
\text { the internet may discourage } \\
\text { frequent integration of ICT into } \\
\text { lecturing }\end{array}$ & $\begin{array}{l}49 \\
(17.6 \%)\end{array}$ & $\begin{array}{l}147 \\
(52.9 \%)\end{array}$ & $\begin{array}{l}61 \\
(21.9 \%)\end{array}$ & $\begin{array}{l}21 \\
(7.6 \%)\end{array}$ & 0.81 & 2.81 \\
\hline $\begin{array}{l}\text { The increase in the level of } \\
\text { absence in the classroom by } \\
\text { sharing courseware on Google } \\
\text { drive hampers usage of ICT } \\
\text { platform for teaching. }\end{array}$ & $\begin{array}{l}76 \\
(27.3 \%)\end{array}$ & $\begin{array}{l}121 \\
(43.5 \%)\end{array}$ & $\begin{array}{l}62 \\
(22.3 \%)\end{array}$ & $\begin{array}{l}19 \\
(6.8 \%)\end{array}$ & 0.88 & 2.91 \\
\hline $\begin{array}{l}\text { Insufficient lecture hours may } \\
\text { not allow the lecturer to cover } \\
\text { the content when using ICT } \\
\text { platform for lecture }\end{array}$ & $\begin{array}{l}67 \\
(24.1 \%)\end{array}$ & $\begin{array}{l}116 \\
(41.7 \%)\end{array}$ & $\begin{array}{l}68 \\
(24.5 \%)\end{array}$ & $\begin{array}{l}27 \\
(9.7 \%)\end{array}$ & 0.92 & 2.80 \\
\hline $\begin{array}{l}\text { Students using ICT platform } \\
\text { mostly for leisure purposes } \\
\text { may hinder the interest of } \\
\text { lecturer for embedding ICT into } \\
\text { Teaching }\end{array}$ & $\begin{array}{l}41 \\
(14.7 \%)\end{array}$ & $\begin{array}{l}108 \\
(38.8 \%)\end{array}$ & $\begin{array}{l}93 \\
(33.5 \%)\end{array}$ & $\begin{array}{l}36 \\
(12.9 \%)\end{array}$ & 0.90 & 2.55 \\
\hline Total & & & & & & \\
\hline
\end{tabular}

Source: Field Survey, 2017. *Mean $\geq 2.5=$ Agreed, Mean $<2.5=$ Disagreed

Responses from table 3 showed that the mean of all the items is $\geq$ 2.5 , which means that the respondents perceptive all the items as reasons for non-usage of University ICT platform by lecturers on Economics Department.

Hypotheses One: There is no significant difference between the perception of male and female economics undergraduate on nonusage of university's ICT platform in teaching economics in University of Ilorin.

Table 4: t-test of Respondents

\begin{tabular}{|l|c|c|c|c|c|c|c|}
\hline Gender & \multicolumn{1}{c|}{ N } & Mean & Std. D & t- cal & df & p-value & Decision \\
\hline Male & 148 & 39.69 & 4.82 & & & & \\
\hline Female & 130 & 39.42 & 4.87 & & & & \\
\hline
\end{tabular}

$\mathbf{P}>\mathbf{0 . 0 5}$ 
Table 4 reveals that $t$-value is 0.46 with significant probability value (P-value) of 0.64 . Since the probability value, $\mathrm{P}$-value $=0.64>0.05$ alpha level, the null hypothesis is therefore not rejected. This implies that no significant difference existed in the perception of economics undergraduate on the basis of their gender.

\section{Hypothesis Two}

$\mathbf{H}_{\mathbf{0} 2}$ : There is no significant difference in perception of undergraduate economics students on non-usage of university's ICT platform in teaching economics in University of Ilorin based on level

Table 5: ANOVA table respondents perception based on level

\begin{tabular}{|l|r|r|r|r|r|l|}
\hline & \multicolumn{1}{|c|}{$\begin{array}{c}\text { Sum of } \\
\text { Squares }\end{array}$} & \multicolumn{1}{|c|}{ df } & \multicolumn{1}{|c|}{$\begin{array}{c}\text { Mean } \\
\text { Square }\end{array}$} & F & Sig. & Decision \\
\hline Between & 495.628 & 3 & 165.209 & & \\
Groups & 5992.574 & 274 & 21.871 & 7.554 & .000 & Significant \\
Within Groups & 6488.201 & 277 & & & \\
Total & & & & & \\
\hline
\end{tabular}

\section{$\mathbf{P}<0.05$ level}

Table 5 shows that F-value is 7.55 with significant probability value (P-value) of 0.00 . Since the probability value, $\mathrm{P}$-value $=0.00<0.05$ alpha level, the null hypothesis is rejected. This implies that significant difference existed in the perception of undergraduate economics students on non-usage of university's ICT platform in teaching economics in University of Ilorin across all levels. This was evident in the Post- Hoc Test where variance existed in the different groups of respondents that are, the Economic undergraduate of 100, 200, 300 and 400 levels respectively. 


\section{Discussion of Findings}

This study has investigated the perception of undergraduate economics students on non-usage of ICT platform for teaching economic in the University of Ilorin. This study has revealed the perception of the student about non-usage of ICT platforms for teaching among which is inadequate power supply as perceived by the majority of students. Also, students believed that process of setting up ICT platform for lectures is timeconsuming to some senior lecturers. Furthermore, the opinion of students signifies the fact that fluctuation in the university's Wi-Fi connection jeopardizes lecturers' interest in using ICT platform for teaching and those incompatible classroom environments make it impossible for utilization of ICT in some situations by lecturers. This finding corroborates that of Lewis and Smith (2002) which revealed the barriers for ICT adoption as follows: limited equipment in the school/ classroom, inadequate skills, minimal support from the school administration, time constraints and the teacher's own lack of interest and belief in the effectiveness of ICT.

Lack of appropriate skills and knowledge in using computers is another factor that was found out to be the hindering integration of ICT platforms for teachings among lecturers, students also perceived lecturers' philosophy regarding appropriate teaching methods determined whether and how they integrate ICT platforms into their teaching. This is in line with Agbamu (2004) whose study revealed that lack of appropriate skills in the use of ICT is one of the determinants of lecturer failure to integrate ICT into their teaching. Also, Ololube, Umunadi and Kpolovie (2014); Kpolovie and Obilor (2013) study's shared the same result by revealed that in Nigeria today, lecturers non-usage ICT services for reasons such as lack of interest, lack of awareness, outrageous rate of service, poor quality of internet service and epileptic power supply. The study also revealed that students' attitude towards plagiarizing answers through the internet may discourage frequent integration of ICT into lecturing while in the same vein, it was brought to a height that increases the level of absence in the 
classroom by sharing courseware on Google drive hamper usage of ICT platform for teaching.

The finding of the study also found that there was no significant difference in the perception of economic undergraduates on non-usage of university ICT platform by their lecturers on the basis of gender. This means that the respondents perceived reasons for non-usage the same way. This could be because all the respondents were exposed to the same teaching and learning situation which could influence them to believe, behave, or feel the same way about issues and challenges. This is confirming the findings of Hall and Langton (2006) who found out that the situation which an individual is exposed to can determine or influence his/her level of perception either positively or otherwise. Thus, this could account for why there was no significant difference in their perception.

While significant difference existed in the economic undergraduate>s perception on the basis of their educational level. This difference could be as a result of the grouping which respondents belong (100, 200, 300 and 400 levels) as well as the characteristics of each group of respondents. This finding is in agreement with the finding of Samar, Azimi and Dadvand (2007) on socioeconomic status and class perception. Their study reveals that differences existed in the perception of people in the society on the basis of their socioeconomic status, even if they are exposed to the same condition.

\section{Conclusion and Recommendations}

In conclusion, how economics undergraduates perceived the non-usage of University ICTs platform for effective teaching do not differ on the basis of their gender but differ on the basis of their educational level (100,200,300 and 400 level). The following recommendations were drawn:

1. Lecturers should try as much as possible to integrate every relevant university ICTs to maximum use to teach.

2. The university administration should entry into Memorandum of 
Understanding $(\mathrm{MoU})$ with software package producers for have access to more software for lecturers to use.

3. There should be adequate provision of facilities and equipment that will enhance using of ICT for teaching economics in University of Ilorin.

4. Encourage the use of visual Google classroom at all levels of the teaching by the university administration. 


\section{References}

Agbamu, T. P. (2004). Restructuring business teacher education through ict driven curriculum. Paper presented at the annual conference of the national association of business educators. University of Calabar

Akuezuilo, E. \& Agu, N. (2003). Research and statistics in education and social sciences. Awka; Nuel centi publishers.

Barron, A. (1998). Designing Web-based training. British Journal of Educational Technology, 29, (4),355-371.

Berge, Z. (1998). Guiding principles in Web-based instructional design. Education Media International, 35,(2),72-76.

Davis, N.E., \& Tearle, P. (Eds.). (1999). A core curriculum for telematics in teacher training. Available: www.ex.ac.uk/telematics.T3/corecurr/ tteach98.htm

Duffy, T., \& Cunningham, D. (1996). Constructivism: Implications for the design and delivery of instruction, Handbook of research for educational telecommunications and technology. New York: MacMillan.

Flecknoe, M. (2002)."How can ICT help us to improve education"? Innovations in Education \& Teaching International, 39,4, 271-280

International Encyclopedia of the Social Sciences (1989) https:// en.wikipedia.org/wiki/International_Encyclopedia_of_the_Social_Sciences

Harris, S. (2002). Innovative pedagogical practices using ICT in schools in England. Journal of $\quad$ Computer Assisted Learning, 7,(18),449458.

Lebow, D. (1993). Constructivist values for instructional systems design: Five principles toward a new mindset. Educational Technology, Research and Development, 41, (3), 4-16.

Littlejohn, A., Suckling, C., Campbell, L. \& McNicol, D. (2002). The amazingly patient tutor: students' interactions with an online carbohydrate chemistry course. British Journal of Educational 
Technology, 33,(3),313-321.

Jonassen, D. H., \& Reeves, T. C. (1996). Learning with technology: Using computers as cognitive tools. In D. H. Jonassen (Ed.), Handbook of research for educational communications and technology (1st ed.). Retrieved from http://www.aect.org/edtech/ed1/

Oliver, R. (2000). Creating Meaningful Contexts for Learning in Webbased Settings. Proceedings of Open Learning 2000. (Pp; 53-62). Brisbane: Learning Network, Queensland

Samar, R. G., Azimi, H. \& Dadvand, B. (2007). Socioeconomic status and class perception. Retrieved from: ww.ijls.net/volumes/ volume1issue3/azimil.pdf

Susman, E. B. (1998). "Co-operative learning: a review of factors that increase the effectiveness of computer-based instruction". Journal of Educational Computing Research,18, (4),303-322.

Smeets, E. (2005). Does ICT contribute to powerful learning environments in primary education? Computers \& Education, 44, 343355.

Tay, L.Y, Lim, S. K; Lim C.P \& Ling Koh, J.H(2012). Pedagogical approaches for ICT integration into primary school English and Mathematics: A Singapore case study)

Tedla, B A. 2012. Understanding the importance, Impacts and Barriers of ICT on Teaching and Learning in East African Countries.

International Journal for e-learning Security, 2, 3/4

The Research Advisors(2006). Sample size table. Retrieved from: http:// research-advisors.com.

Wheeler, S. (2001). Information and communication technologies and the changing role of the teacher. Journal of Educational Media, 26, (1), 7-17.

Yusuf, M.O. (2005). Information and communication education: Analyzing the Nigerian national policy for information technology. International Education Journal, 6 (3), 316-321.

Zhao, Y. \& Cziko, G. A. (2001). Teacher adoption of technology: a perceptual control theory perspective. Journal of Technology and Teacher Education, 9,(1), 5-30. 